\title{
The Gender Wage Gap in Switzerland over Time
}

\author{
Flurina Schmid* \\ * Swiss Centre of Expertise in Social Sciences (FORS), University of Lausanne, CH-1015 Lausanne, \\ flurina.schmid@fors.unil.ch.
}

\begin{abstract}
s
The Gender Wage Gap in Switzerland over Time

This article analyzes the gender wage gap in Switzerland, using data from the Swiss Household Panel. The results show that women in Switzerland earn still less than men with the same endowments. One of the main reasons for this gap is occupational segregation: women and men working in femaledominated occupations have lower wages than those in integrated and male-dominated occupations. In order to have equally distributed job categories, $40 \%$ of the male or female employees would need to change jobs. But the "preferences" for jobs between genders seem to have been frozen for decades. The gender wage gap is particularly large within part-time employees working below 50\%. Younger cohorts, however, seem less exposed to gender wage differentials.
\end{abstract}

Keywords: Gender discrimination, human capital, occupational gender segregation, part-time, wage gap

\section{Geschlechtsspezifische Lohnungleichheit in der Schweiz im Zeitverlauf}

Dieser Artikel untersucht geschlechtsspezifische Lohnungleichheiten anhand der Daten des Schweizer Haushalt-Panels. Die Resultate zeigen, dass Frauen in der Schweiz nach wie vor tiefere Löhne haben als Männer mit denselben Austattungsmerkmalen. Einer der Hauptgründe für Lohnunterschiede ist die berufliche Segregation zwischen den Geschlechtern: Frauen wie auch Männer, die in typischen Frauenberufen arbeiten, haben tiefere Löhne als solche, die in durchmischten oder männerdominierten Berufen arbeiten. Um diese berufliche Segregation auf dem Arbeitsmarkt auszugleichen, müssten 40\% des einen Geschlechts die Stelle wechseln. Die «Berufsvorlieben» der Geschlechter scheinen jedoch seit Jahrzehnten unverändert. Ein besonders grosses Lohngefälle zeichnet sich zwischen weiblichen und männlichen Teilzeitarbeitenden ab, die unter 50\% arbeiten. Das geschlechtsspezifische Lohngefälle ist bei jüngeren Kohorten dafür weniger ausgeprägt.

Schlüsselwörter: Geschlechter-Diskriminierung, Humankapital, berufliche Geschlechtersegregation, Teilzeit, Einkommensunterschiede

\section{La discrimination salariale entre hommes et femmes en Suisse au fil du temps}

Cet article étudie les inégalités salariales entre les sexes à partir des données du Panel suisse de ménages. Les résultats montrent qu’à caractéristiques d'emploi égales, les salaires des femmes en Suisse sont toujours inférieurs à ceux des hommes. L'une des principales raisons est la ségrégation professionnelle: les femmes et les hommes travaillant dans des emplois typiquement féminins ont des salaires plus modestes que ceux occupés dans des emplois mixtes ou dominés par les hommes. Afin d'éliminer cette ségrégation, $40 \%$ des travailleurs ou travailleuses devraient changer d'emploi. Mais les "préférences professionnelles» selon le genre semblent figées depuis des décennies. L'écart de rémunération parmi les salariées à temps-partiel travaillant moins de $50 \%$ est particulièrement grand. Les différences salariales sont, cependant, moins prononcées auprès des jeunes cohortes.

Mots-clés: Discrimination sexuelle, capital humain, ségrégation professionnelle de genre, temps partiel, inégalités salariales 


\title{
The Gender Wage Gap in Switzerland over Time
}

\author{
Flurina Schmid*
}

Gender wage discrimination occurs when male and female workers receive different wages for the same performance or the same endowments. Using for the first time the Swiss Household Panel (SHP) ${ }^{1}$ data to explore the gender wage gap, this article examines whether gender wage differences, after controlling for differences in human capital and employment characteristics, differ between cohorts. Furthermore, it deals with the main factors that lead to wage discrimination against women and tries to explain why discrimination persists.

Female emancipation started in Switzerland in the $19^{\text {th }}$ century. Legally, however, women have only recently been granted equal rights. They gained the right to vote in 1971, since 1981 the principle of gender equality is anchored in the Swiss Federal Constitution ${ }^{2}$ and a law guaranteeing a legitimate and compelling claim to earn the same wage for equivalent work has been in place since 1996. Fifteen years later, women still earn around 15\% less than men on average (FSO 2012a): men have a monthly median salary of $6840 \mathrm{CHF}$ and women have a median salary of 5808 CHF (in full-time equivalents).

According to the Social Policy Division of the Organisation for Economic Co-operation and Development (OECD), the gender wage differences in 2009 were the highest worldwide in Asian OECD countries when the median wage gaps between men and women working full-time were compared (OECD 2011). The smallest gaps were found in Belgium, Greece, Hungary, New Zealand, and Norway. Switzerland was above the OECD average with wage differentials of $19 \%$.

The gender wage gap usually can partly be explained by human capital and job characteristics, but a considerable part cannot be explained by these factors. It thus stands to reason that this unexplained part must be due to discrimination.

* Swiss Centre of Expertise in Social Sciences (FORS), University of Lausanne, CH-1015 Lausanne, flurina.schmid@fors.unil.ch.

1 This study has been realized using the data collected by the Swiss Household Panel (SHP), which is based at the Swiss Centre of Expertise in the Social Sciences FORS. The project is financed by the Swiss National Science Foundation.

2 The exact wording in the Constitution is «L'homme et la femme sont égaux en droit. La loi pourvoit à l'égalité de droit et de fait, en particulier dans les domaines de la famille, de la formation et du travail. L'homme et la femme ont droit à un salaire égal pour un travail de valeur égale.» 
However, depending on the completeness of the included factors ${ }^{3}$ and the data set, the unexplained part varies a lot, thus the expression "discrimination" has to be used with caution. According to the Swiss Federal Statistical Office, this unexplained part has only slightly decreased in the private sector - from $10.6 \%$ to $9.4 \%$ between 1998 and 2008 (Strub and Stocker 2010). Bonjour and Gerfin (2001), who based their study on the Swiss Labor Force Survey, found that women in low paid jobs face the highest unexplained part. The reasons for wage discrimination are various and complex. Therefore, significant changes in short intervals are rather unlikely, and the comparison of cohorts turns out to be more interesting.

\section{Theoretical framework: explanations for the existence of wage discrimination}

The following approaches try to explain why women are paid less than men. The first section focuses on arguments originating from the labor-supply side, explaining the individual's preferences for a job. The second section addresses the labor-demand side, explaining the employer's labor preferences, that is to say why an employer might pay lower wages to women. Section three describes the compensating differentials theory, an approach that concentrates on non-wage arguments, bringing together employers and workers with common interests, and the last section presents employment-related characteristics with an impact on the hourly wage.

\subsection{Discrimination from the supply side}

From a human capital perspective, workers supply their human capital, such as skills and knowledge, to the employer (Becker 1962). Generally human capital endowments are seen in society as a legitimate source of earning differentials (Olsen and Walby 2004). Investing in education or growing labor market experience is supposed to have a positive impact on one's future real income. However, not everyone has the same "utility" to invest in human capital, which in consequence leads to wage differences. It is not always easy to distinguish between discriminatory and "justified" wage differences. From the beginning of someone's career, there is some kind of gender-specific self-selection process because women and men have heterogeneous tastes for jobs. Women with family intentions might, for example, invest less in human capital, when long working breaks are scheduled (Achatz et al. 2004; Busch and Holst 2011). They might also choose jobs that can be easily combined with family life, such as part-time jobs, jobs close to the nursery and jobs with a high starting wage but smaller returns to experience (Achatz et al. 2004; Finzi 2007). Men who intend to stay in the labor market for many uninterrupted years

3 If many relevant characteristics are not available in the data set (also called "measure of ignorance"), the unexplained part becomes bigger (see for more details Mincer 1985). 
will choose, according to this logic, an occupation with a high return to experience. Granato and Schittenhelm (2001) pointed out that selection of gender-specific jobs starts at a prevocational point in time. The professional orientation is highly influenced by family and individuals of the same age. Women often restrict themselves by reproducing the career path of female reference persons with a similar social background (Granato and Schittenhelm 2001). Haeberlin et al. (2005) found that by secondary school, girls already have significantly lower career aspirations than boys, which ultimately hampers their career opportunities.

Another approach states that women and men behave in traditional social roles because they are used to them and because it is socially expected: " $[\mathrm{M}]$ en have traditionally functioned in roles that are enhanced by assertiveness (e. g., aggressive breadwinner, powerful boss, authoritative father), whereas women have traditionally acted as advocates (e. g., supportive assistant, encouraging wife, prodding mother)" (Wade 2001, 66). According to this approach, women are not used to making requests on their own behalf. In line with this, many studies confirm that women submit lower wage bids (Rigdon 2012; Dittrich et al. 2014).

The fact that the labor market structure is not always adapted to women's family projections has consequences for how couples organize their family life. The most common family model for parents in Switzerland is that the father works full-time and the mother not at all or part-time (FSO 2013). According to Becker (1962), specialization and division of labor are reasons why women in a partnership have a tendency to choose part-time jobs or to stay at home, which has an important impact on the level of one's work experience. When spouses specialize in specific tasks - one is in charge of the housework tasks, and the other pursues paid work - they are more productive. The parent staying at home with the child is probably the one with the lower salary - usually the woman. Single women, with and without children, do not have the choice of dividing housework tasks and paid work, thus they are expected to have more similar wage patterns to men than women in a partnership. Reducing employment for each parent to create an equally shared parenting situation is often not possible because not every employer is in favor of part-time employment, and the parents have to find care for their child with relatives or a nursery. Furthermore, it is likely that wage differences also exist between individuals who have children or who dedicate their life mainly to the family, and those who do not have children and can concentrate entirely on their career.

\subsection{Discrimination from the demand side}

The demand side refers to the employer's demand for a labor force. The following three economic theories explain why discrimination by the employer exists: monopsony in the labor market, statistical discrimination, and the perception of men's and women's behavior. 


\subsubsection{Monopsony power}

Monopsony in the labor market starts with the idea that wages relative to productivity depend on the elasticity of the labor supply. A single employer in a competitive labor market pays different wages to different groups even when the marginal revenue product is the same. Having on average more family responsibilities, women are said to have a less elastic labor supply curve - they react less sensitively to wage cuts, because they bear more costs changing employers. Furthermore, it is proved that men change jobs in Switzerland more often than women for career reasons (FSO 2012 b), which could be a sign that they react more sensitively to wage cuts, when the salary is not sufficient.

Having fewer family responsibilities, men are particularly mobile within the labor market (Barth and Dale-Olsen 2009). They are, for example, more flexible in the choice of work and working places and are therefore more willing to commute longer distances than women. Women, in contrast, are said to be less mobile - that is to say both geographically and occupationally: they prefer a job close to the nursery even if they are underpaid (Hirsch et al. 2010), and they are also ready to accept a job that fits with family life but not necessarily with their skills. The employer, knowing this, can take advantage of it. According to Cardwell and Rosenzweig (1980, 1103), "[T] he prerequisite for such monopsony power is a labor force with relatively few job alternatives." Limited job selection can create occupational segregation, meaning the concentration of men and women in different job categories. The findings in the literature show that the higher the share of women in a certain job sector, the lower the overall wage (e.g., Treiman and Hartmann 1981; England et al. 1988; Busch and Holst 2011; Busch 2013). Bertschy et al. (2014) found for Switzerland that women earn on average the highest salary in typically female job sectors and less in equally shared or male-dominated job sectors, but less than men in general, regardless of the job sector. Lalive and Stutzer (2010) found that the Swiss gender pay gap is smaller in liberal communities (often cities) compared to traditional communities (often the countryside). A reason for this could be that employers in rural areas have more monopsony power than those in cities, the density of jobs being lower in rural regions.

Recent monopsony models show, however, that monopsony power also exists in competitive markets with more than one employer (Manning 2003). Because of frictions in the labor market, imperfect information, heterogeneous preferences among workers, and mobility costs, the labor supply curves are upward sloping at the firm level, meaning that small wage cuts do not necessarily lead workers to quit their jobs. It also turned out that female labor supply is equally, or even more, wage sensitive than men's labor supply at the market level. For example, it is socially more accepted when women move in and out of the labor market for family reasons. Men if often being under pressure as main income providers, quit the labor market less 
easily. Manning (2003) therefore suggests that women's labor supply is less elastic than men's at the firm level, but not at the aggregated level of the labor supply.

\subsubsection{Statistical discrimination}

Discrimination can also happen when the employer ignores the true economic efficiency of a group (Becker 1971). Statistical discrimination means that the employer remunerates performance according to an average performance of a group and not due to individual performance (Bielby and Baron 1986). Groups with below-average productivity or a below-average commitment level are often victims of statistical discrimination. Women particularly differ from men in their turnover rate. They have a higher probability of leaving the labor market to raise children (Sousa-Poza 2002). Turnover costs for finding and training new employees can lead the employer to underestimating some women's commitment to work by paying them a lower wage. Or worse, employers reserve jobs with high replacement costs for groups with greater expected productivity (Bielby and Baron 1986), leading to occupational segregation. Changing jobs is therefore expected to be more advantageous for men than for women.

Hirsch (2005) argued that workers' skills are heterogeneous - having fewer skills results in a lower salary. He assumed that part-time jobs demand fewer skills than full-time jobs do, so the hourly wage is lower. Linking part-time work with fewer skills is much contested and might depend a lot on the job itself, but it explains why an employer may underestimate part-time worker productivity. Another reason for the part-time penalty is that the average hourly cost of part-time relative to full-time workers (e. g., in hiring and training) is proportionally higher for a part-time worker. In other words, part-time workers, assuming they are equally motivated to work as their full-time colleagues, which is debatable, allegedly to bring in less money in the same time interval but they cost the employer the same. In addition, as women make up the majority of part-time workers in Switzerland (FSO 2012c), the profitability of hiring a man is probabilistically higher for the employer (Moro 2009).

A similar mechanism is at stake for temporary work, but this time men should be disadvantaged: because men in average work more often temporarily than women, employers might think that men are generally less committed to their job and place them in jobs where less firm-specific skills are used. Temporary job positions often require fewer skills and responsibilities, which may justify a lower wage. However, this is not the case for those with equal responsibilities and skills. At the same time, temporary workers serve as a buffer for demand shocks (Santangelo 2011). When the economy worsens, the first employees who are fired or are not replaced are individuals with limited contracts. Thus, anticipating employers investing less in temporary workers, such as by giving them less work-related training and less welfare protection. In this case, if there is an hourly wage differential, temporary 
workers with the same human capital endowments as permanent workers should theoretically receive more because they cost the employer less.

\subsubsection{The different perceptions of men's and women's behavior}

Another type of discrimination comes from the different perceptions of men's and women's behavior (Schubert 1997). There are cultural beliefs about the status associating greater competence to some groups, such as mechanical ability for men and domestic skills for women. These gender status beliefs are persistent because they are culturally widely shared and transmitted (Ridgeway 2001). A study based on Swiss data shows that male and female test subjects assign generally less wage to women than to men for the same job, being equally qualified (Jann 2008). A lot of stereotypes regarding gender still exist. Women are characterized by soft attributes (emotionality, passivity, weakness, etc.) and men by hard attributes (rationality, aggressiveness, etc.). The issue is not whether this is true, but rather that stereotypes are a problem when the employer associates hard attributes with more performance than soft attributes. Shirazi et al. (2002) found, for example, a negative relationship between salary and typical female traits. Typical women's work is still assigned a lesser value than men's, and there is even a general devaluation of female-dominated job sectors with the consequence of lower wages for women and men in such sectors (Busch and Holst 2011). England et al. (2007) found, however, almost no evidence that the feminization of occupations lowers wages, and no evidence at all that a fall in occupations' relative wages leads to feminization. She thinks that there might have been an initial correlation between gender composition and wages that has been frozen by institutional inertia ever since.

\subsection{The compensating wage differential}

Another approach explaining the gender wage gap is the idea of compensating differentials: it states that non-wage job benefits and detriments determine the attractiveness of an occupation. Employers pay wage rates depending on the "ease or hardship" (Smith 1937 [1776]) of the work: in this view a dangerous workplace, for example, is meant to be compensated with a higher pay while a job with flexible working hours should lead to lower pay. Following that logic, part-time work or typical female jobs are paid less because of desirable working conditions. Budig and England (2001) tested whether a mother's jobs are less demanding or offer motherfriendly characteristics but found only little evidence apart from the fact that they are often part-time. Felfe (2012) also explored the "motherhood wage gap" and found that women who change employers after the birth of a child not only reduce working hours significantly but also look for jobs with more convenient hours (less work at night) and more flexible working schedules, and they indicate to be less exposed to stress. A study from Switzerland based on the data of the Swiss Labor 
Market Survey 1998 shows a similar conclusion: women being doubly loaded with job and family responsibilities chose less demanding jobs ${ }^{4}$ (Engelhardt and Jann 2004).

\subsection{Employment characteristics}

Finally, company-related characteristics play a role in the gender wage gap. Holding a management position is for obvious reasons expected to be positively linked with hourly wages. In addition, the firm size can have a positive impact on wages due to lower transaction costs and better opportunities for promotion in larger firms (Van der Meer and Wielers 1998; Strub and Stocker 2010). However, it is not very clear whether the firm size has an impact on the level of discrimination: they might be less likely to discriminate because in larger firms there are more written rules to prevent discrimination, but at the same time small firms might be rather new in the market adopting very market-oriented, modern and efficient policies in order to be competitive (Jolliffe and Campos 2005).

Working in the private or the public sector leads usually to different wages, too. The private sector is subject to profit constraints while the public sector depends on taxpayers. The literature is very controversial as to answering the questions in which sector overall wage and discrimination are higher. For Switzerland, recent data show that the public sector pays higher wages than the private sector (FSO 2012d). According to Falter and Ferro-Luzzi (2000), wage discrimination happens less in the public sector as fairness and job security are supposed to have priority in this sector. Moreover, Robinson (1998) argued that public employees are usually classified in a job grade, to which a pay scale is applied, which makes it more difficult to discriminate. In contrast, Weber and Zulehner (2014) reasoned the other way round: It is inefficient to pay different wages for the same marginal productivity, which is why competitive environments (the private sector) are supposed to create less discrimination.

\section{Data and descriptive statistics}

This study is based on the data of the SHP, a yearly panel study following a random sample of households in Switzerland over time and interviewing all household members, mainly by CATI ${ }^{5}$. The SHP started in 1999 with a first sample of 12931 household members. In 2004, a second sample with 6569 individuals was added. The SHP was only rarely used for gender gap-related issues, and it is unique not only because of its longitudinal design but also because it contains a broad choice

4 The variable "commitment to work" which is supposed to measure how demanding a job is, is derived from self-estimated statements.

5 Computer Assisted Telephone Interview. 
of variables, such as the commuting distance or the number of children, which do not exist in other Swiss surveys.

For this paper, only the years 2004 to 2012 are taken into account because some of the used variables did not exist before. People under 21 are not part of the sample because predicted values would overestimate the wages of young people. Furthermore, persons at retirement age (65 for men and 64 for women) as well as inactive and self-employed people are excluded $(\mathrm{N}=3043)$. Nevertheless, I can rely on 15655 observations (7615 men, 8040 women). The data are weighted to keep the estimates representative of the baseline population (SHP participants in 2004). This means that only the original sample members (OSM) - those who participated in 2004 - are taken into account in this paper. The results do not vary a lot when weighting, but the drawback is that excluding the non-original sample members, the number of individuals decreases.

In 2012, if everyone worked full-time, the monthly gross median income would have amounted to $6788 \mathrm{CHF}$. Nevertheless, there was a huge difference between male and female wages. From 2004 to 2012, men's monthly median wage increased from 6918 to $7275 \mathrm{CHF}$ while women's monthly median rose proportionally more but on a lower level, from 5600 to $6291 \mathrm{CHF}$.

The dependent variable is the "logarithm of gross hourly wage." ${ }^{6}$ It is computed by taking the monthly gross income and dividing it by the monthly working hours according to the working contract (overtime is not included).

The following variables are part of the baseline equation and are in literature often used to measure the gender wage gap. The constructed variable "years of schooling" (based on the educational level) is inspired by the codebook for the Cross-National Equivalent File 1999-2009 (Lipps and Kuhn 2009) and includes schooling years ranging from 9 to 20 years. ${ }^{7}$ The variable "experience" contains the number of years spent in paid work. When individuals participate in the panel for the first time, they are asked how many years they have spent at work without counting interruptions. For every additional year they participate, while still remunerated at work, an additional year is added. Literature suggests diminishing marginal returns to experience, meaning that at some point in time, experience can also have a negative impact on wages (Mincer 1970). That is why a squared version of this variable is also included. To avoid a high correlation between the squared and the unsquared terms, the variable experience is first mean-centered and then squared. Age is not a variable used because it correlates highly with experience.

$6 \quad$ Including the $13^{\text {th }}$ and $14^{\text {th }}$ month salary, bonuses, and gratifications.

7 Individuals with a compulsory school education are assigned nine years of education. People with a domestic science course receive 10 years of schooling. Those with a general training, an apprenticeship, full-time vocational or maturity (Swiss high school diploma), get 12 years of schooling. Vocational high school, technical, or vocational school corresponds to 15 years, and university is supposed to take 17 years (maturity plus three years for bachelor's degree, plus two years for master's degree). Finally, people with a doctorate get an additional three years of schooling. 
The "firm size 1/2/3/4" variable distinguishes between small enterprises with 1-9, enterprises with 10-49, enterprises with 50-499, and large firms with 500 employees or more. All other variables of the baseline equation are dummies too. The "female" variable distinguishes between men (0) and women (1); "job position" is a dummy in which 1 means having a management position and 0 means having a position below management; the "contract" variable stands for having a time-limited (0) or unlimited (1) working contract; "change of employer" indicates whether someone changed the employer; "public/private sector" indicates in which sector someone works. And "regions" distinguishes between the following greater regions": Genferseeregion (VD, VS, GE), Mittelland (BE, FR, SO, NE, JU), Nordwestschweiz (BS, BL, AG), Zürich, Ostschweiz (GL, SH, AR, AI, SG, GR, TG), Zentral Schweiz (LU, UR, SZ, OW, NW, ZG), and Tessin (TI). They are also introduced as dummies, and Genferseeregion is the reference category.

The augmented equation includes additional, non-job-related variables that could have an impact on wage. The variable "alone/couple" is a dummy and distinguishes between individuals being alone and individuals with a partner. Alone can be single, separated, never married, divorced, or widowed. With a partner means being married or in a registered partnership. For the "activity rate," the distinction is made between working $0-50 \%,>50 \%-90 \%$, or more than $90 \%$. The variable "commuting" indicates the number of minutes commuted daily. Individuals working at home are considered to have 0 minutes of commuting. Sales representatives, who daily change their way to work, are lumped into the missing category as there is no indication about the average commuting distance. To control for occupational "segregation," a variable measuring the distribution of men and women in any given occupation is used. The variable is based on the International Standard of Classification of Occupations (ISCO-88), classified at the 2-digit level of ISCO, and distinguishes between female-dominated jobs (70-100\% are women per given occupation), male-dominated (30\% or less are women), and more or less equally shared occupations (more than $30 \%$ and less than $70 \%$ are women) (Busch and Holst 2011). The reference category is the one with the female-dominated occupations.

\section{$4 \quad$ Empirical models}

When studying the gender wage gap over time, often the Oaxaca Blinder decomposition method is applied. It divides the wage gap into an explained (differences in human capital endowments) and an unexplained part (the so called "discriminatory component" of the gap) (see, e. g., Oaxaca 2007). Applying this approach to the SHP data, the gender wage gap remains almost the same between 2004 and 2012: overall, men earned $20 \%$ more than women and almost half could not be

8 Official distinction used by the Federal Statistical Office. 
explained by the explanatory variables, which usually is referred to discrimination. Large changes in a time frame of only 9 years are not realistic, thus the focus in this paper is on the comparison of cohorts.

This paper starts exploring the evolution of the unexplained gender wage gap by comparing cohorts. To measure causal impacts and not selectivity, fixed effects, i. e. measuring the variability within subjects over time, would be an appropriate approach. But as the gender does usually not change over time, fixed effects are not possible here. Instead, a hybrid approach is used, which overcomes the problem of unobserved heterogeneity by combining random and fixed effects. The second analysis keeps its focus on the reasons why women are paid differently for the same endowments. As arguments of both a causal and selective nature can be the source of wage differentials, fixed and random effects are depicted. The third analysis compares different activity rates, as Switzerland is a country where women have an above-average part-time rate. For already-mentioned reasons, the hybrid approach is used again. The last step consists of computing Duncan's segregation index to learn more about gender distribution across occupation sectors.

There will be two equations: the baseline equation, which contains the classic gender gap variables on which one's salary usually depends, and the augmented version, which includes additional variables that could have an impact on the hourly wage.

The baseline equation and the augmented version are as follows:

$$
\begin{aligned}
& y_{1}=a_{0}+b_{1} X_{i}+b_{2} D_{i}+e_{i} \\
& y_{1}=a_{0}+b_{1} X_{i}+b_{2} D_{i}+b_{3} A D D_{i}+u_{i}
\end{aligned}
$$

where $y_{i}$ is the log of hourly wage; $X_{i}$ stands for human capital and employment characteristics; and $D_{i}$ represents the gender dummy where the designation 0 stands for men and 1 for women. The coefficient that goes with the gender dummy, if significant, indicates the percentage of salary discrimination (Strub 2005). $A D D_{i}$ includes all the additional variables in the augmented version, and $e_{i}$ and $u_{i}$ are the error terms. The formulas for the augmented equation will not be given every time in the formulas that follow.

The random effects model measures the difference between (different) persons. It is usually used when $x_{i t}$ and $a_{i}$ are uncorrelated, $\left(E\left(a_{i} \mid x_{i}\right)=0\right)$.

$$
y_{i t}=a_{i}+b_{1} X_{t}+b_{2} D+e_{t}
$$

Fixed effects measure the difference within persons by removing any time-invariant component of the model. Fixed effects control for unobserved heterogeneity that is constant over time. Contrary to the random effect model, fixed effects assume that the individual-specific effect is correlated with the independent variables $\left(E\left(a_{i} \mid x_{t}\right) \neq 0\right)$. One limitation of fixed-effect models is that they cannot estimate effects of variables that vary across individuals but not over time. 


$$
y_{i t}-\bar{y}_{i}=\left(a_{0}-\bar{a}_{0}\right)+b_{1}\left(x_{t}-\bar{x}_{i}\right)+\left(e_{t}-\bar{e}_{i}\right)
$$

where $a_{0}-\bar{a}_{0}=0$.

The hybrid model (Allison 2009; Brüderl 2010) is one way to circumvent the fixed-effects problem with time-invariant variables such as gender. In short, it estimates pure within and pure between effects. By transforming the independent time-variant variables into a within and a between component and by leaving the time-invariant variables unchanged, a random model can be estimated. The results are that the within estimators are exactly the same as they would be in the fixedeffects model, except that there is now also a within estimator for the time-invariant variable (gender). Nevertheless, if there is unobserved heterogeneity, the estimator for the time-invariant variable will be biased and must be interpreted carefully. In the final output, only the fixed-effects coefficients and the time-invariant gender dummy are depicted.

$$
y_{i t}=\left(a_{0}-\bar{a}_{0}\right)+\bar{a}_{0}+b_{1}\left(x_{t}-\bar{x}_{i}\right)+b_{1} \bar{x}_{i}+b_{2} D+\left(e_{t}-\bar{e}_{i}\right)+\bar{e}_{i}
$$

The Duncan segregation index is computed with the ISCO-88 classification (International Standard of Classification of Occupations, 4-digit ISCO occupational code) and contains 214 job categories.

$$
I=\frac{1}{2} \sum_{i=1}^{n}\left|M_{i} / M-F_{i} / F\right|
$$

where $F_{i}$ is the number of women in occupation i; $M_{i}$ the number of men in occupation $\mathrm{i}$; and $F$ is the number of women and $M$ is the number of men in the labor force.

For every job category, the (noncumulative) percentages of men and women are computed and then the female percentages are subtracted from the male percentages. The computed absolute values per job category are then added, and the result is divided by two. The final result indicates how many women (men) must change jobs to have equally distributed job categories.

\section{Empirical results}

\subsection{Hybrid effects: cohorts}

In order to see how the unexplained gender wage gap differs between cohorts, three age groups are compared. Group 1 includes individuals born after 1968, group 2 includes individuals born from 1954-1968, and group 3 includes those who were born before 1954. By transforming the independent time-variant variables manually into a within and a between component and by leaving the time-invariant variables unchanged, a random model can be estimated. Here the focus is only on the within (fixed-effects) components. 
Table $1 \quad$ Baseline regression with hybrid effects: gender wage gap between cohorts

\begin{tabular}{|c|c|c|c|}
\hline Variables & $>1969$ & 1954-1968 & $<1953$ \\
\hline \multirow[t]{2}{*}{ Years of schooling } & $0.030 * * *$ & 0.007 & 0.007 \\
\hline & $(0.005)$ & $(0.004)$ & $(0.010)$ \\
\hline \multirow[t]{2}{*}{ Experience centered } & 0.0261 ** & -0.003 & 0.000 \\
\hline & $(0.010)$ & $(0.006)$ & $(0.016)$ \\
\hline \multirow[t]{2}{*}{ Experience squared } & $-0.001^{* * *}$ & $-0.000^{* * *}$ & $-0.000^{*}$ \\
\hline & $(0.000)$ & $(0.000)$ & $(0.000)$ \\
\hline \multirow[t]{2}{*}{ Public/private sector } & $-0.047^{* * *}$ & -0.010 & 0.005 \\
\hline & $(0.014)$ & $(0.009)$ & $(0.020)$ \\
\hline \multirow[t]{2}{*}{ Firm size 2} & $0.072^{* * *}$ & 0.005 & 0.037 \\
\hline & $(0.017)$ & $(0.012)$ & $(0.026)$ \\
\hline \multirow[t]{2}{*}{ Firm size 3} & $0.075^{* * *}$ & $0.026^{*}$ & 0.038 \\
\hline & $(0.018)$ & $(0.013)$ & $(0.028)$ \\
\hline \multirow[t]{2}{*}{ Firm size 4} & $0.098 * * *$ & $0.028^{*}$ & 0.057 \\
\hline & $(0.020)$ & $(0.014)$ & $(0.030)$ \\
\hline \multirow[t]{2}{*}{ Job position } & 0.033 & 0.026 & -0.032 \\
\hline & $(0.023)$ & $(0.014)$ & $(0.029)$ \\
\hline \multirow[t]{2}{*}{ Contract } & $0.269 * * *$ & $0.052 * * *$ & 0.009 \\
\hline & $(0.019)$ & $(0.015)$ & $(0.030)$ \\
\hline \multirow[t]{2}{*}{ Change of employer } & $0.045^{* * *}$ & -0.012 & 0.042 \\
\hline & $(0.012)$ & $(0.010)$ & $(0.030)$ \\
\hline \multicolumn{4}{|l|}{ Controls } \\
\hline \multicolumn{4}{|l|}{ Between controls } \\
\hline \multirow[t]{2}{*}{ Female } & $-0.065^{* *}$ & $-0.125^{* * *}$ & $-0.265^{* * *}$ \\
\hline & $(0.022)$ & $(0.018)$ & $(0.041)$ \\
\hline \multirow[t]{2}{*}{ Constant } & $2.705^{* * *}$ & $3.492^{* * *}$ & $3.549 * * *$ \\
\hline & $(0.100)$ & $(0.084)$ & $(0.175)$ \\
\hline R-sq: within & 0.233 & 0.049 & 0.022 \\
\hline R-sq: between & 0.443 & 0.423 & 0.447 \\
\hline Observations & 4588 & 8693 & 2374 \\
\hline Individual identification number & 967 & 1609 & 467 \\
\hline
\end{tabular}

Standard errors in brackets, $p$-values: ${ }^{* * *} p \leq 0.001,{ }^{* *} p \leq 0.01,{ }^{*} p \leq 0.5$.

Source: Swiss Household Panel.

The variable of interest in Table 1 is the gender dummy - other impacts will be discussed later in more detail. It can be seen that the unexplained part decreases from one cohort to the other. The oldest cohort shows a gap of $-27 \%$, the middle-aged 
group one of $-13 \%$, and the youngest faces a gap of only $-7 \%$. The differences from cohort 1 to cohorts 2 and 3 are statistically significant. ${ }^{9}$ An age effect cannot be excluded; it could be that the gender gap increases with family foundation and bringing up children. But also the youngest cohort is affected by these reasons; women's average age in this cohort is 31 , close to the age when a Swiss woman has on average her first child (FSO 2014). And still the gap is very low compared to the other cohorts. The table also shows that the younger the cohort, the more significant the fixed-effects coefficients. The explanation for the sometimes very low significance levels is that fixed effects measure only time-variant variables, and employment changes probably happen in the first place to young males and females. This is, for example, plausible for additional schooling years, as we tend to increase them when we are young.

Overall, the comparison of different cohorts shows that the younger the cohort, the smaller the unexplained part (which is supposed to reflect discrimination).

\subsection{Fixed and random effects: gender-specific regressions}

This part of the section is no longer about the size of the gender wage gap, but about the possible causes of discrimination. In order to see if men and women are rewarded the same for equal endowments, two augmented regressions, one per gender, are compared.

Table 2 represents the coefficients for both a fixed-and random-effect model. As expected, the coefficients of schooling years are positive for men and women per additional schooling year, the hourly wage increases. Also the coefficients of experience show, as the theory assumes, decreasing returns on experience. But men reach their maximum wage faster than women; maybe because women have to interrupt their careers for family life or because men, having fewer family duties, choose, from the beginning of their career, an occupation with a high return to experience. Setting the two experience terms to zero, the initial wage can be established; but against theory, women do not have higher initial wages, on the contrary, their jobs seem to be from the beginning lower paid than men's. Furthermore, the public sector in Switzerland does pay higher wages than the private sector, which is particularly true for women. Changing from a small to a bigger firm increases the hourly wage - again the impact is more pronounced for women. Both genders earn more when holding a management position, and having a stable working contract pays better than being in a time-limited job position, above all for men. They earn 21\% more when changing the contract type, while it is only $14 \%$ for women. This could be a sign that women change their contract type mainly to

$9 \quad$ In order to do a significance test, two groups (e. g. cohort $1 \& 2$ ) were pooled together each time and an interaction term (e.g. the product of the gender dummy and the dummy of cohort $1 \& 2$ ) was added to the regression. The detection of the group effect is based on the sign of interaction and the t-test for significance. 
Table 2 Augmented regression with fixed and random effects: causes of discrimination

\begin{tabular}{|c|c|c|c|c|c|c|}
\hline \multirow[t]{2}{*}{ Variables } & \multicolumn{3}{|c|}{ Fixed effects } & \multicolumn{3}{|c|}{ Random effects } \\
\hline & Men & Women & $\begin{array}{r}\text { Coefficient } \\
\text { for interaction } \\
\text { with gender }\end{array}$ & Men & Women & $\begin{array}{r}\text { Coefficient } \\
\text { for interaction } \\
\text { with gender }\end{array}$ \\
\hline \multirow[t]{2}{*}{ Years of schooling } & $0.032^{* * *}$ & $0.022^{* * *}$ & -0.007 & $0.065^{* * *}$ & $0.054^{* * *}$ & -0.004 \\
\hline & $(0.004)$ & $(0.004)$ & $(0.006)$ & $(0.003)$ & $(0.003)$ & $(0.004)$ \\
\hline \multirow[t]{2}{*}{ Experience centered } & -0.004 & $0.017^{*}$ & 0.003 & $0.010^{* * *}$ & $0.010 * * *$ & $0.004^{* * *}$ \\
\hline & $(0.006)$ & $(0.008)$ & $(0.002)$ & $(0.001)$ & $(0.001)$ & $(0.001)$ \\
\hline \multirow[t]{2}{*}{ Experience squared } & $-0.001 * * *$ & $-0.001^{* * *}$ & $0.000^{*}$ & $-0.001^{* * *}$ & $-0.001^{* * *}$ & 0.000 \\
\hline & $(0.000)$ & $(0.000)$ & $(0.000)$ & $(0.000)$ & $(0.000)$ & $(0.000)$ \\
\hline \multirow[t]{2}{*}{ Public/private sector } & -0.005 & $-0.039 * * *$ & $-0.038^{* *}$ & -0.015 & $-0.061^{* * *}$ & $-0.042^{* *}$ \\
\hline & $(0.010)$ & $(0.011)$ & $(0.014)$ & $(0.009)$ & $(0.010)$ & $(0.0129)$ \\
\hline \multirow[t]{2}{*}{ Firm size 2} & $0.037^{* *}$ & $0.042^{* *}$ & -0.015 & $0.042^{* * *}$ & $0.058^{* * *}$ & -0.005 \\
\hline & $(0.012)$ & $(0.014)$ & $(0.013)$ & $(0.012)$ & $(0.013)$ & $(0.012)$ \\
\hline \multirow[t]{2}{*}{ Firm size 3} & $0.043^{* *}$ & $0.0645^{* * *}$ & 0.006 & $0.062^{* * *}$ & $0.086^{* * *}$ & 0.007 \\
\hline & $(0.0130)$ & $(0.015)$ & $(0.012)$ & $(0.012)$ & $(0.013)$ & $(0.011)$ \\
\hline \multirow[t]{2}{*}{ Firm size 4} & $0.054^{* * *}$ & $0.093^{* * *}$ & 0.025 & $0.091^{* * *}$ & $0.121 * * *$ & 0.015 \\
\hline & $(0.0138)$ & $(0.017)$ & $(0.015)$ & $(0.013)$ & $(0.015)$ & $(0.014)$ \\
\hline \multirow[t]{2}{*}{ Job position } & 0.017 & 0.029 & 0.012 & $0.062^{* * *}$ & $0.067^{\star * *}$ & -0.00236 \\
\hline & $(0.012)$ & $(0.021)$ & $(0.024)$ & $(0.012)$ & $(0.020)$ & $(0.023)$ \\
\hline \multirow[t]{2}{*}{ Contract } & $0.210 * * *$ & $0.135^{* * *}$ & $-0.076^{* * *}$ & $0.225^{* * *}$ & $0.139^{* * *}$ & $-0.090^{* * *}$ \\
\hline & $(0.014)$ & $(0.017)$ & $(0.021)$ & $(0.013)$ & $(0.016)$ & $(0.020)$ \\
\hline \multirow[t]{2}{*}{ Change of employer } & $0.027^{* *}$ & 0.015 & -0.010 & 0.013 & 0.001 & 0.009 \\
\hline & $(0.010)$ & $(0.011)$ & $(0.014)$ & $(0.009)$ & $(0.010)$ & $(0.014)$ \\
\hline \multirow[t]{2}{*}{ Activity rate 2} & $-0.133^{* * *}$ & $-0.044^{* * *}$ & $0.033^{*}$ & $-0.161^{* * *}$ & -0.011 & $0.047^{* *}$ \\
\hline & $(0.020)$ & $(0.0127)$ & $(0.017)$ & $(0.019)$ & $(0.011)$ & $(0.0153)$ \\
\hline \multirow[t]{2}{*}{ Activity rate 3} & $-0.177^{* * *}$ & $-0.104^{* * *}$ & 0.006 & $-0.198^{* * *}$ & $-0.076^{* * *}$ & 0.024 \\
\hline & $(0.019)$ & $(0.016)$ & $(0.017)$ & $(0.018)$ & $(0.014)$ & $(0.015)$ \\
\hline \multirow[t]{2}{*}{ Segregation 2} & 0.014 & $0.057^{* * *}$ & 0.011 & $0.040 * *$ & $0.059 * * *$ & -0.001 \\
\hline & $(0.016)$ & $(0.016)$ & $(0.018)$ & $(0.014)$ & $(0.0123)$ & $(0.015)$ \\
\hline \multirow[t]{2}{*}{ Segregation 3} & 0.008 & $0.067^{* *}$ & 0.034 & 0.040 ** & $0.084^{* * *}$ & $0.037^{*}$ \\
\hline & $(0.017)$ & $(0.022)$ & $(0.021)$ & $(0.014)$ & $(0.019)$ & $(0.0184)$ \\
\hline \multirow[t]{2}{*}{ Commuting } & $0.000^{*}$ & -0.000 & -0.000 & $0.000 * *$ & 0.000 & 0.000 \\
\hline & 0.000 & $(0.000)$ & $(0.000)$ & 0.000 & $(0.000)$ & $(0.000)$ \\
\hline \multirow[t]{2}{*}{ Alone/couple } & -0.022 & -0.012 & 0.002 & 0.001 & -0.024 & $-0.073^{* * *}$ \\
\hline & $(0.013)$ & $(0.016)$ & $(0.020)$ & $(0.012)$ & $(0.013)$ & $(0.0159)$ \\
\hline \multirow[t]{2}{*}{ Children centered } & 0.005 & 0.001 & 0.010 & $0.022^{* * *}$ & $-0.024^{* *}$ & $0.014^{*}$ \\
\hline & $(0.010)$ & $(0.013)$ & $(0.010)$ & $(0.006)$ & $(0.007)$ & $(0.006)$ \\
\hline \multirow[t]{2}{*}{ Children squared } & -0.006 & 0.001 & -0.009 & $-0.013^{* * *}$ & 0.004 & $-0.055^{* * *}$ \\
\hline & $(0.006)$ & $(0.008)$ & $(0.014)$ & $(0.004)$ & $(0.005)$ & $(0.008)$ \\
\hline
\end{tabular}


Continuation of table 2.

\begin{tabular}{l|cc|cc}
\hline Variables & \multicolumn{3}{|c|}{ Fixed effects } & \multicolumn{2}{c}{$\begin{array}{c}\text { Random effects } \\
\text { Men }\end{array}$} & Women & $\begin{array}{r}\text { Coefficient } \\
\text { for interaction } \\
\text { with gender }\end{array}$ & Men & Women & $\begin{array}{r}\text { Coefficient } \\
\text { for interaction } \\
\text { with gender }\end{array}$ \\
\hline Controls & & & & $2.791^{* * *}$ \\
Constant & $3.166^{* * *}$ & $3.014^{* * *}$ & $2.643^{* * *}$ \\
& $(0.079)$ & $(0.106)$ & $0.046)$ & $(0.048)$ \\
Observations & 7615 & 8040 & 7615 & 8040 \\
R-squared & 0.157 & 0.115 & 0.460 & 0.269 \\
Individual identifica- & 1418 & 1625 & 1418 & 1625 \\
tion number & & & & \\
\hline
\end{tabular}

Standard errors in brackets, $p$-values: ${ }^{* * *} p \leq 0.001,{ }^{* *} p \leq 0.01,{ }^{*} p \leq 0.5$.

See footnote 9 to see how the significance tests were conducted.

Source: Swiss Household Panel.

adapt to their family situation and less to improve wages. In terms of figures, men still make up the majority of the steadily increasing number of temporary workers in Switzerland (Spichiger and Osterfeld 2015). Changing employers has only a positive and significant impact on the hourly wage for men. Again, it shows that men probably change jobs to earn more, while women might have other reasons than a wage increase. The activity rate coefficients are at first sight a bit of a surprise: Random and fixed effects show that the lower the activity rate, the higher the hourly wage. This effect is even stronger for men. In other words, individuals who work part-time earn proportionally more than their full-time colleagues, and those who change from full- to part-time experience an hourly wage increase. In a study based on the Swiss Labour Force Survey 2005, the same results were found: parttime employees working between $70 \%$ and $89 \%$ have significantly higher hourly wages, whereas for those below $50 \%$, the conclusions were less clear due to too small a sample size (FSO 2006). Taking a closer look at the SHP's male and female part-time workers in 2012, it appears that today's average part-time workers are as well educated as average full-time workers, and $18 \%$ of them indicate not being interested in a full-time job. ${ }^{10}$ Another explanatory fact could be that individuals who change their activity rate make sure usually that their hourly wage does not decrease. Part of the explanation, mainly for men, could also be that there are few male individuals who work less than $50 \%$ of the time, and some of them earn high salaries. It is also known that self-estimated wages can lead to bias where some groups of individuals overestimate their working hours. Last not least, it could also be that individuals with a low activity level, a low hourly wage, and no additional

$1013 \%$ of men and $19 \%$ of women indicate not being interested in working full-time. 
financial support (e.g., from the government or partner) would probably look for a second job, while those who earn enough might prefer to work fewer hours and have more leisure time. Contrary to the results of a recent TREE study (Bertschy et al. 2014), the SHP data show that women generally earn more in integrated and male occupations than in female-dominated occupations. And changing from a female-dominated occupation into an integrated or male-dominated occupation leads to a wage increase of $6 \%$ and $7 \%$, respectively. But it has to be said that few women change directly from a female- to a male-dominated occupation, and there might be a selection effect. ${ }^{11}$ At the same time, many women change from a female to an integrated occupation, and they face a significant wage increase, as well.

The results might be different from those of TREE because TREE is based on very young individuals who are at the beginning of their career. The coefficients of Table 2 show that female-dominated occupations have on average a lower wage level than male-dominated occupations, which is confirmed by the mentioned TREE study. Considering that according to the SHP data in 2012, over $50 \%$ of women worked in female-dominated occupations, the impact is not to be neglected and underlines that typical female occupations might still be considered to be less valuable. Adding the segregation variable to the baseline regression (not depicted), it comes out that occupational segregation accounts for a quarter of the gender wage gap. Furthermore, men's hourly wage increases with the distance commuted, but compared to women, the coefficients are not significantly different. In general, men commute on average more than women; this holds for all years between 2004 and 2012 and supports the assumption that men are geographically more mobile than women. Getting married or having an additional child has no impact on someone's wage, but there is a difference between women in a partnership and single women; the latter generally earn more. Comparing men and women, there is also a difference between those who have children and those who do not; for men, the return to children decreases per additional child, while it has a purely negative impact on women. Becker's (1962) specialization and division of labor theory makes sense here; men with children concentrate on their career while women keep their focus on the family.

Men's and women's random effects R-squares explain $46 \%$ and $27 \%$, respectively, of the regression. Apparently, the chosen variables explain men's wages better than women's. It can be speculated that today's criteria for equal pay are too heavily based on men's strengths. The fixed-effects models have lower R-squares, as they only measure changes that actually happened between 2004 and 2012 .

In summary, it was found that part-time work for both genders goes along with a higher hourly wage than full-time work. Furthermore, women have a significantly lower starting wage per hour than men. In addition, discrimination shows up in a hidden way: individuals, whether men or women, working in female-dominated

11 E.g. the few women who change from a female into a male dominated job sector might be especially tough. 
occupations generally earn less than elsewhere, and it is self-explanatory that women are (in terms of figures) more affected by this phenomenon. Furthermore, comparing women with and without children, or married and unmarried women, family-oriented women earn on average less. Women often have to choose between family and career, while men can have both.

\subsection{Hybrid effects: part-time versus full-time}

Part-time positions for women in Switzerland are common; over 50\% work part-time according to the Swiss Federal Statistical Office (FSO 2012c), and the SHP data confirm this fact. Moreover, $48 \%$ of these females indicate that they work part-time for family reasons, and $19 \%$ do it by choice. The following analysis measures the gender wage gap for different rates of activity.

Table 3 shows that the unexplained part of the gender wage gap within full-time workers is around $-10 \%$. Part-time workers working between $>50 \%$ and $90 \%$ have with $-5 \%$ a clearly smaller unexplained part. Exposed to the highest gap (-18\%) are men and women working less than $50 \%$ - in terms of figures, there are many more women working in this category.

The number of schooling years is above all important for persons working fulltime: the higher the education, the higher the wage. The coefficients for experience, if significant, show diminishing returns. Changing jobs between the public and private sector impacts only the salary of those working between $>50 \%$ and $90 \%$ significantly. The firm size matters a lot for individuals with a very low activity rate; they can increase their hourly wage by $19 \%$ when changing from a very small to a very big firm. The contract, on the other hand, plays a very important role for full-time workers. Changing from an unstable contract to a stable one increases the hourly wage by $30 \%$. Changing jobs increases the hourly wage, at least for the first two groups, in a statistically significant way.

Overall, it may be said that part-time workers are a very heterogeneous group, while women with a very low activity rate are exposed to a high gender gap; the other female part-time workers (between $>50 \%$ and 90\%) risk even less gender discrimination than their female full-time working colleagues.

\subsection{Duncan's segregation index}

As shown in Section 5.2, segregation is an important argument for wage discrimination. Men and women working in female-dominated occupations earn lower wages, and women can increase their wages when changing to an integrated or male-dominated job sector. Applying Duncan's segregation index, which measures how many women/men must change jobs to have equally distributed job categories, Sousa-Poza (2003) found that from 1991-2001, 40\% ${ }^{12}$ of women/men should

12 The study is based on the Swiss Labor Force Survey (SLFS). 
Table 3 Baseline regression with hybrid effects: gender wage gap according activity rate

\begin{tabular}{|c|c|c|c|}
\hline Variables & Full-time (>90\%) & Part-time (>50\%-90\%) & Part-time $(<50 \%)$ \\
\hline \multirow[t]{2}{*}{ Years of schooling } & $0.027^{* * *}$ & 0.005 & 0.004 \\
\hline & $(0.003)$ & $(0.006)$ & $(0.010)$ \\
\hline \multirow[t]{2}{*}{ Experience centered } & 0.001 & $-0.031^{*}$ & 0.023 \\
\hline & $(0.005)$ & $(0.012)$ & $(0.022)$ \\
\hline \multirow[t]{2}{*}{ Experience squared } & $-0.001 * * *$ & $-0.000 * * *$ & $-0.000^{*}$ \\
\hline & $(0.000)$ & $(0.000)$ & $(0.000)$ \\
\hline \multirow[t]{2}{*}{ Public/private sector } & -0.007 & $-0.040^{* *}$ & 0.01 \\
\hline & $(0.008)$ & $(0.014)$ & $(0.025)$ \\
\hline \multirow[t]{2}{*}{ Firm size 2} & $0.026^{*}$ & $0.038^{*}$ & $0.094^{* * *}$ \\
\hline & $(0.011)$ & $(0.018)$ & $(0.028)$ \\
\hline \multirow[t]{2}{*}{ Firm size 3} & $0.039^{* * *}$ & 0.007 & $0.154^{* * *}$ \\
\hline & $(0.011)$ & $(0.019)$ & $(0.032)$ \\
\hline \multirow[t]{2}{*}{ Firm size 4} & $0.058^{* * *}$ & 0.025 & $0.191^{* * *}$ \\
\hline & $(0.012)$ & $(0.022)$ & $(0.036)$ \\
\hline \multirow[t]{2}{*}{ Job position } & $0.024^{*}$ & -0.001 & -0.008 \\
\hline & $(0.010)$ & $(0.024)$ & $(0.062)$ \\
\hline \multirow[t]{2}{*}{ Contract } & $0.303^{* * *}$ & $0.152^{* * *}$ & 0.027 \\
\hline & $(0.013)$ & $(0.022)$ & $(0.033)$ \\
\hline \multirow[t]{2}{*}{ Change of employer } & $0.027^{* * *}$ & $0.035^{*}$ & 0.032 \\
\hline & $(0.007)$ & $(0.014)$ & $(0.025)$ \\
\hline \multicolumn{4}{|l|}{ Controls } \\
\hline \multicolumn{4}{|l|}{ Between controls } \\
\hline \multirow[t]{2}{*}{ Female } & $-0.097^{* * *}$ & $-0.048^{*}$ & $-0.183^{* * *}$ \\
\hline & $(0.015)$ & $(0.022)$ & $(0.043)$ \\
\hline \multirow[t]{2}{*}{ Constant } & $2.963^{* * *}$ & $3.383^{* * *}$ & $3.286^{* * *}$ \\
\hline & $(0.065)$ & $(0.165)$ & $(0.338)$ \\
\hline Observations & 8561 & 3898 & 3196 \\
\hline R-sq: within & 0.2157 & 0.1059 & 0.0395 \\
\hline R-sq: between & 0.5166 & 0.3634 & 0.193 \\
\hline Individual identification number & 1903 & 1095 & 996 \\
\hline
\end{tabular}

Standard errors in brackets, $p$-values: ${ }^{* * *} p \leq 0.001,{ }^{* *} p \leq 0.01,{ }^{*} p \leq 0.5$.

Source: Swiss Household Panel.

have changed jobs. The same analyses for the years 2004-2012 with the SHP data show again that every year, around $40 \%$ of women/men "should" change jobs to have equally distributed job categories. Today's work force in Switzerland is still 
segregated. It looks like the job preferences of men and women did not change over time. A reason for this could be that individuals reproduce the career path of reference persons from the same gender; for example, daughters copy their mothers (Granato and Schittenhelm 2001). And Morgan et al. (2013) found that selection into gender-specific occupations starts early. Occupational plans ${ }^{13}$ of high school students are strong predictors of the initial choice of a college major. Another persisting problem in this context is that typical female jobs are still valued less than typical male jobs, which might be due to persisting gender status beliefs (Ridgeway 2001). In addition, England (2010) mentioned that since the 1960s, women have had strong incentives to enter male-dominated occupations while there were almost no incentives for men to work in female activities.

In short, sex segregation by occupation can lead to discrimination, such as when typical female jobs are less valued than typical male jobs. Based on the past 20 years, there is no prospect of change for job preferences among genders.

\section{Conclusions}

In this paper the gender wage gap in Switzerland is analyzed, exploiting for the first time longitudinal data from the SHP. In order to overcome the problem of unobserved heterogeneity, hybrid models are employed when fixed effects are not possible.

There are still major unexplained wage differences between women and men, but according to the data it seems that this gap gets smaller from one cohort to the other. ${ }^{14}$

The hourly wage, the dependent variable, is influenced by many factors, and the reasons for discrimination are sometimes difficult to assess. Both genders earn more when holding a management position. Additional years of education and labor market experience have a positive impact on the hourly wage of both genders too, but men's investment is slightly more remunerated. It is possible that men choose from the beginning jobs with higher returns to experience because the probability that they have to interrupt their career for family reasons is rather small. It is, however, as theory assumes, not true, that women have higher initial wages.

Discrimination has a lot to do with preferences and priorities (within the limits of the Swiss labor market). Women might anticipate their family life and choose jobs that allow or simplify a life with children (part-time, close to nursery, etc.), accepting jobs that fit with their family life but not necessarily with their qualifications. From an economic view, regardless of whether they are happy in their job,

13 In a self-administered questionnaire the students had to write the job or occupation that they expected or planned to have at the age 30 .

14 Still it could be partly due to age effects. But thanks to the unique character of the SHP data, it will be possible to verify how the relatively small gender wage gap of the youngest cohort evolves in the coming years. 
overqualified women are a market failure because the labor market suffers from not fully exhausting the potential of its active population.

Selection into gender-specific jobs plays a key role in the emergence of the gender pay gap. Most women work in female-dominated occupations, which unfortunately often go with a lower wage level. Changing from a female-dominated to an integrated or male-dominated occupation appears to be financially advantageous for women. It is difficult to say if typical female jobs are particularly easy and therefore low-paid or if they are low-paid because the accumulation of women in a job sector has a detrimental effect on wage. A classical example is the care sector: most of the care specialists are women, wages are low, and the employee turnover rate is high (Cattaneo and Kwiatecki 2012). Solutions to the resulting labor shortage would be better working conditions, higher wages, and a better work-family balance (Lampart 2014). But social habits and values cannot be changed from one day to an other, as Duncan's segregation index shows: since (at least) 1991, the gender distribution across jobs has persistently remained unbalanced, with around $40 \%$ of women or men needing to change jobs to have equally distributed job categories.

This paper also shows that in Switzerland the public sector pays higher wages than the private sector - a result that is confirmed by another gender wage gap analysis realized through the Swiss Federal Statistical Office (Strub and Stocker 2010). It is financially particularly attractive for women working or changing to the public sector. This is not surprising as the Federal Administration undertook many measures to promote gender equality for their own employees. Furthermore, it became apparent that part-time workers earn proportionally more than full-time workers, and there is no evidence that part-time working women (the majority in Switzerland) are more discriminated in terms of wages than full-time working women. Within part-time employees, the gender wage gap is the biggest for those working below 50\%; this fact is particularly damaging for women, insofar that the majority at this activity rate is female. The smallest gap turned up within part-time workers working at least 50\%. Full-time workers are in between these two categories. Overall, part-time workers are a very heterogeneous group: on the one hand, some work at very low wage levels, and on the other hand, others earn quite well.

The assumption that changing employer is more advantageous for men can be confirmed. Men usually increase their wages when changing employer, for women there is no such impact at all. It can be speculated that men change them to earn more while women change jobs rather to adapt their professional situation to the private one, such as having a job closer to the nursery. Other explanations could be that employers underestimate women's commitment to work because of the higher turnover rate by paying them less or that women do not bargain well enough when starting a new job. Furthermore, the change of the contract type is linked to an employment change and proves to be financially advantageous mainly for men. Changing from a temporary to a fix-term contract, for example, is especially 
interesting for young persons, full-time workers, and men. Moreover, men's hourly wage increases with the distance commuted, which could be interpreted that they are ready to commute more for a higher salary. The same effect for women is not significant; higher pay does not provide enough incentive for women to commute more (or commuting more is for women simply not related to a wage increase). Generally, men commute on average longer distances than women, which speaks for the hypothesis that women "prefer" staying closer to their home. Changing from a small to a bigger firm increases the hourly wage for both genders. The impact is slightly stronger for women, which shows that larger firms generally reflect a more equal pay-related environment.

Couples in Switzerland are often double-wage earners, allowing one of them to work less or to accept a low-paid job. Discrimination is not always a market failure. A more extensive division of labor raises productivity. Nevertheless, why do women specialize in household tasks while men do the paid work? It is not always clear what is imposed by the market and what is an individual choice. All in all, it seems that women get the short straw as soon as family plays a role. At least, there are no effects on wage when men and women become a couple or have an additional child. But comparing different groups, it comes out that female singles earn more than women in a partnership, while there is no difference among men of different marital status. The situation is similar between those with and without children: men with children generally earn more while women with children on average earn less.

Are women constrained to self-select into family-oriented types and careeroriented types? If this is the case, the government can intervene through several measures. Concretely, the work-family balance must be optimized by relieving women from their family duties if that is what they want. A special eye should be kept on those job sectors that were less attractive to women until now. A remedy would be, above all in the private sector, the creation of more incentives for women, but also for men, to enter occupations typical of the opposite sex. A more balanced gender distribution across occupations could result in more equal wages between genders and enable more men to work part-time. Promoting more and cheaper child nurseries would be a first step in harmonizing women's and men's work-family balance as well. Following the Nordic countries' example, another measure could be to give parents the possibility to split parental leave. In this way, a reasonable child care situation can be assured without forcing women to stay at home. The positive side-effect of this measure would be the reduction of statistical discrimination because the employer's profitability of hiring a man would no longer be probabilistically higher. Quotas to increase female participation are only useful where women have the same access to the labor market as men and if they are not forced to leave the labor market or to interrupt their career for family reasons.

In this paper only the active population is taken into account, women who do not work at all are not considered. There might be discriminating reasons, to 
be explored in further research, that prevent them from entering the labor market. Another important limitation is due to how the data was collected: In the SHP the hourly wage is based on self-estimated statements, which leads to less precise answers compared to other data sets where the employer gives the information concerning his employees directly. In return the SHP covers a broad range of topics which do not exist elsewhere. For example, it would be interesting to know more about the impact of child care or if and how a woman changes professional habits after having a child.

\section{$7 \quad$ References}

Achatz, Juliane, Hermann Gartner, and Timea Glück. 2004. Bonus oder Bias? Mechanismen geschlechtsspezifischer Entlohnung. IAB-Discussion Paper, http://www.iab.de/de/publikationen/discussionpaper/publikationendetails-discussion-paper.aspx/Publikation/k040722a01 (14.01.2015).

Allison, Paul D. 2009. Fixed Effects Regression Models. Thousand Oaks: Sage.

Barth, Erling, and Harald Dale-Olsen. 2009. Monopsonistic Discrimination, Worker Turnover, and the Gender Wage Gap. IZA Discussion Paper 3930, http://ftp.iza.org/dp3930.pdf (14.01.2015).

Becker, Gary S. 1962. Investment in Human Capital: A Theoretical Analysis. Journal of Political Economy 70(5): 9-49.

Becker, Gary S. 1971. The Economics of Discrimination. Chicago: The University of Chicago Press.

Bertschy, Kathrin, Philipp Walker, Annick Baeriswyl, and Michael Marti. 2014. Lohndiskriminierung beim Berufseinstieg. Eine quantitative Analyse für die Schweiz. Swiss Journal of Sociology 40(2): 279-305.

Bielby, William T., and James N. Baron. 1986. Men and Women at Work: Sex Segregation and Statistical Discrimination. American Journal of Sociology 91(4): 759-799.

Bonjour, Dorothe, and Michael Gerfin. 2001. The Unequal Distribution of Unequal Pay - An Empirical Analysis of the Gender Wage Gap in Switzerland. Empirical Economics 26(2): 407-427.

Brüderl, Josef. 2010. Kausalanalyse mit Paneldaten, in Handbuch der sozialwissenschaftlichen Datenanalyse. Pp. 963-994 in Handbuch der sozialwissenschaftlichen Datenanalyse, edited by Christof Wolf and Henning Best. Wiesenbaden: VS-Verlag.

Budig, Michelle J., and Paula England. 2001. The Wage Penalty for Motherhood. American Sociological Review 66(2): 204-225.

Busch, Anne. 2013. Der Einfluss der beruflichen Geschlechtersegregation auf den "Gender Pay Gap" Zur Bedeutung geschlechtlich konnotierter Arbeitsinhalte. Kölner Zeitschrift für Soziologie und Sozialpsychologie 65(2): 301-338.

Busch, Anne, and Elke Holst. 2011. Gender-Specific Occupational Segregation, Glass Ceiling Effects, and Earnings in Managerial Positions: Results of a Fixed Effects Model. DIW Berlin Discussion Paper 1101, http://www.diw.de/documents/publikationen/73/diw_01.c.367559.de/dp1101. pdf (14.01.2015).

Cardwell, Lucy A., and Mark Richard Rosenzweig. 1980. Economic Mobility, Monopsonistic Discrimination and Sex Differences in Wages. Southern Economic Journal 46(4): 1102-1117.

Cattaneo Pierino, and Martin Th. Kwiatecki. 2012. Im Gesundheitswesen sind Rekordmarken an Stellenwechseln zu beobachten Fluktuationskosten - der überunterschätzte Kostentreiber. Clinicum 6, http://www.clinicum.ch/images/getFile?t=ausgabe_artikel\&f=dokument\&id=452 (14.01.2015). 
Dittrich, Marcus, Andreas Knabe, and Kristina Leipold. 2014. Gender Differences in Experimental Wage Negociations. Economic Inquiry 52(2): 862-873.

Engelhardt, Henriette, and Ben Jann. 2004. Halbe Kraft voraus? Arbeitseinsatz, berufliche Segregation und Löhne von Frauen auf dem Schweizer Arbeitsmark. Soziale Welt 55(2): 205-224.

England, Paula. 2010. The Gender Revolution: Uneven and Stalled. Gender \& Society 24(2): 149-166.

England, Paula, Paul Allison, and Yuxiao Wu. 2007. Does Bad Pay Cause Occupations to Feminize, Does Feminization Reduce Pay, and How Can We Tell with Longitudinal Data? Social Science Research 36(3): 1237-1256.

England, Paula, George Farkas, Barbara Stanek Kilbourne, and Thomas Dou. 1988. Explaining Occupational Sex Segregation and Wages: Findings from a Model with Fixed Effects. American Sociological Review 53(4): 544-558.

Falter, Jean-Marc, and Giovanni Ferro-Luzzi. 2000. Public - Private Sector Wage Differentials in Switzerland. Zeitschrift für Volkswirtschaft und Statistik 136(3): 319-339.

Felfe, Andrea Christina. 2012. The Child Penalty - What about Job Amenities? Labour Economics 19(1): 59-67.

Finzi, Illaria. 2007. Occupational Gender Segregation and Gender Wage Gap in Switzerland. PhD dissertation, Faculty of Economics, University of Lugano, Switzerland.

FSO (Federal Statistical Office). 2006. Teilzeitarbeit in der Schweiz. BFS Aktuell. Neuchâtel: FSO.

FSO (Federal Statistical Office). 2012a. Frauen und Erwerbslosigkeit: anhaltende Unterschiede zwischen Frauen und Männern bei der Erwerbslosenquote. BFS Aktuell. Neuchâtel: FSO.

FSO (Federal Statistical Office). 2012b. Die berufliche Mobilität. Eine Analyse aufgrund der Ergebnisse der Schweizerischen Arbeitskräfteerhebung (SAKE) von 1993 bis 2011. BFS Aktuell. Neuchâtel: FSO.

FSO (Federal Statistical Office). 2012c. Ergebnisse der Schweizerischen Lohnstrukturerhebung 2012. Neuchâtel: FSO.

FSO (Federal Statistical Office). 2012d. Wages and income from employment - Indicators. Wage Level in the Public Sector - 2012, http://www.bfs.admin.ch/bfs/portal/en/index/themen/03/04/blank/ key/lohnstruktur/im_oeffentlichen_sektor.html (15.12.2014).

FSO (Federal Statistical Office). 2013. Das Engagement der Väter in Haushalt und Familie - Modul zur unbezahlten Arbeit 2010 der Schweizerischen Arbeitskräfteerhebung. BFS Aktuell. Neuchâtel: FSO.

FSO (Federal Statistical Office). 2014. Bevölkerungsbewegung - Indikatoren. Durchschnittsalter der verheirateten Mütter bei der Erstgeburt, http://www.bfs.admin.ch/bfs/portal/de/index/the$\mathrm{men} / 01 / 06 / \mathrm{blank} / \mathrm{key} / 02 / 07 . \mathrm{html}(26.02 .2016)$.

Granato, Mona, and Karin Schittenhelm. 2001. Perspektiven junger Frauen beim Übergang zwischen Schule und Ausbildung. BWP Berufsbildung in Wissenschaft und Praxis 6: 13-17.

Haeberlin, Urs, Christian Imdorf, and Winfried Kronig. 2005. Verzerrte Chancen auf dem Lehrstellenmarkt. Untersuchungen zu Benachteiligungen von ausländischen und von weiblichen Jugendlichen bei der Suche nach beruflichen Ausbildungsplätzen in der Schweiz. Zeitschrift für Pädagogik 51(1): 116-134.

Hirsch, Barry. 2005. Why Do Part-Time Workers Earn Less? The Role of Worker and Job Skills. Industrial and Labor Relations Review 58(4): 525-551.

Hirsch, Barry, Thorsten Schank, and Claus Schnabel. 2010. Differences in Labor Supply to Monopsonistic Firms and the Gender Pay Gap: An Empirical Analysis Using Linked Employer-Employee Data from Germany. Journal of Labor Economics 28(2): 291-330.

Jann, Ben. 2008. Lohngerechtigkeit und Geschlechterdiskriminierung. Evidenz aus einem VignettenExperiment. Pp. 107-124 in Erwerbsarbeit, Einkommen und Geschlecht. Studien zum Schweizer Arbeitsmarkt, edited by Ben Jann. Wiesbaden: VS Verlag.

Jolliffe, Dean, and Nauro F. Campos. 2005. Does Market Liberalization Reduce Gender Discrimination? Econometric evidence from Hungary, 1986-1998. Labour Economics 12(1): 1-22. 
Lalive, Rafael, and Alois Stutzer. 2010. Approval of Equal Rights and Gender Differences in Well-being. Journal of Population Economics 23(3): 933-962.

Lampart, Daniel. 2014. «Fachkräftemangel» im Gesundheitswesen durch bessere Löhne und Arbeitsbedingungen entschärfen - ein Blick in Studien zum Thema. Politnetz, http://www.politnetz.ch/ artikel/21009-fachkraeftemangel-im-gesundheitswesen (14.01.2015).

Lipps, Oliver, and Ursina Kuhn. 2009. Codebook for CNEF Variables in the SHP (1999-2007). Data Documentation. Swiss Household Panel, http://aresoas.unil.ch/workingpapers/WP5_09.pdf (26.02.2016)

Manning, Alan. 2003. Monopsony in Motion: Imperfect Competition in Labor Markets. Princeton: Princeton University Press.

Mincer, Jacob. 1970. The Distribution of Labor Incomes: A Survey with Special Reference to the Human Capital Approach. Journal of Economic Literature 8(1): 1-26.

Mincer, Jacob. 1985. Intercountry Comparisons of Labor Force Trends and of Related Developments: An Overview. Journal of Labor Economics 3(1): 1-32.

Morgan, Stephen L., Dafna Gelbgiser, and Kim A. Weeden. 2013. Feeding the Pipeline: Gender, Occupational Plans, and College Major Selection. Social Science Research 42(4): 989-1005.

Moro, Andrea. 2009. Statistical Discrimination. In The New Palgrave Dictionary of Economics. Online edition, edited by Steven N. Durlauf and Lawrence E. Blume. Palgrave Macmillan, http://www. dictionaryofeconomics.com/article?id=pde2009_S000544 (03.10.2013).

Oaxaca, Ronald L. 2007. The Challenge of Measuring Labour Market Discrimination Against Women. Swedish Economic Policy Review 14(1): 199-231.

OECD (The Organisation for Economic Co-operation and Development). 2011. OECD Family Database, http://www.oecd.org/els/LMF_1_5_Gender_pay_gaps_for_full_time_workers.pdf (26.02.2016).

Olsen, Wendy, and Sylvia Walby. 2004. Modelling Gender Pay Gaps. EOC Working Paper Series, http:// www.leeds.ac.uk/sociology/people/swdocs/Modelling\%20gender\%20pay\%20gaps\%20WP\%20 17.pdf (14.01.2015).

Ridgeway, Cecilia L. 2001. Gender, Status, and Leadership. Journal of Social Issues 57(4): 637-655.

Rigdon, Mary. 2012. An Experimental Investigation of Gender Differences in Wage Negotiations, http:// papers.ssrn.com/sol3/papers.cfm?abstract_id=2165253 (14.01.2015).

Robinson, Derek. 1998. Differences in Occupational Earnings by Sex. International Labour Review 137(1): 3-31.

Santangelo, Giulia. 2011. Do Temporary Contracts Cause Wage Discrimination? Paper presented at the XXV National Conference of Labour Economics. Milano, Italy, September 15, 2011.

Schubert, Renate. 1997. Discrimination in the Labor Market: A Gender Perspective. Pp. 98-122 in Economic Policy in Switzerland, edited by Philippe Bacchetta and Walter Wasserfallen. London: Macmillan Press.

Shirazi, Rez, Anders Biel, and Fransson Niklas. 2002. Integrating Determinants of Sexism and Gender Wage Gap in Naturalistic Work Settings. Göteborg Psychological Reports 32(3).

Smith, Adam. 1937 [1776]. An Inquiry into the Nature and Causes of the Wealth of Nations. New York: Modern Library.

Sousa-Poza, Alfonso. 2002. Labor-Market Segmentation and the Gender Wage Differential: An IndustryLevel Analysis Using Data from the 1998 Swiss Wage Structure Survey. Cahiers Economiques de Bruxelles 45(2): 91-118.

Sousa-Poza, Alfonso. 2003. The Gender Wage Gap and Occupational Segregation in Switzerland, 1991-2001. Swiss Journal of Sociology 29(3): 399-415.

Spichiger, Peter, and Marius Osterfeld. 2015. Die Temporärarbeit in der Schweiz, Aktualisierungsstudie 2014. Swissstaffing, http://swissstaffing.ch/fileadmin/customer/Branche/Studien/Aktualisierungsstudie_2014.pdf (29.10.2015). 
Strub, Silvia. 2005. Approche méthodologique relative au contrôle de l'égalité salariale entre femmes et hommes dans les marchés publics de la Confédération. Büro für arbeits- und sozialpolitische Studien BASS, http://www.ebg.admin.ch/dokumentation/00012/00194/00205/?lang=fr (14.01.2015).

Strub, Silvia, and Désirée Stocker. 2010. Analyse der Löhne von Frauen und Männern anhand der Lohnstrukturerhebung 2008. Büro für arbeits- und sozialpolitische Studien BASS, http://www. bfs.admin.ch/bfs/portal/fr/index/news/publikationen.html?publicationID=4062 (14.01.2015).

Treiman, Donald J., and Heidi I. Hartmann (Eds.). 1981. Women, Work, and Wages: Equal Pay for Jobs of Equal Value. Washington, D.C.: National Academy Press.

Van der Meer, Peter, and Rudi Wielers. 1998. Hierarchy, Wages and Firm Size. Acta Sociologica 41(2): $163-172$.

Wade, Mary E. 2001. Women and Salary Negociation: The Costs of Self-Advocacy. American Psychological Association 25(1): 65-76.

Weber, Andrea, and Christine Zulehner. 2014. Competition and Gender Prejudice: Are Discriminatory Employers Doomed to Fail? Journal of the European Economic Association 12(2): 492-521. 